\title{
Carbazole-Phenylbenzotriazole Copolymers as Absorber Material in Organic Solar Cells
}

\author{
Michael F. G. Klein, ${ }^{\dagger}$ Felix M. Pasker, ${ }^{\ddagger}$ Stefan Kowarik, ${ }^{\S}$ Dominik Landerer, ${ }^{\dagger}$ Marina Pfaff,,$\| \perp$
} Matthias Isen, ${ }^{\dagger}$ Dagmar Gerthsen, ${ }^{\|, \perp}$ Uli Lemmer, ${ }^{\dagger, \perp}$ Sigurd Höger, ${ }^{*, \dagger}$ and Alexander Colsmann ${ }^{*, \dagger, \perp}$

${ }^{\dagger}$ Light Technology Institute, Karlsruhe Institute of Technology (KIT), Engesserstraße 13, 76131 Karlsruhe, Germany

${ }^{\ddagger}$ Kekulé-Institut für Organische Chemie und Biochemie, Rheinische Friedrich-Wilhelms-Universität Bonn, Gerhard-Domagk-Straße 1, 53121 Bonn, Germany

${ }^{\S}$ Institut für Physik, Humboldt-Universität zu Berlin, Newtonstraße 15, 12489 Berlin, Germany

"Laboratory for Electron Microscopy, Karlsruhe Institute of Technology (KIT), Kaiserstraße 12, 76131 Karlsruhe, Germany

${ }^{\perp}$ Center for Functional Nanostructures, Karlsruhe Institute of Technology (KIT), Wolfgang-Gaede-Straße 1a, 76131 Karlsruhe, Germany

\section{Supporting Information}

ABSTRACT: An alternating copolymer comprising a 2,7functionalized carbazole donor and a 2-phenyl-2 $\mathrm{H}$-benzotriazole acceptor with an octyldodecyloxy substituent was synthesized. The polymer was blended with $[6,6]$-phenyl $\mathrm{C}_{71}$-butyric acid methyl ester $\left(\mathrm{PC}_{71} \mathrm{BM}\right)$ and incorporated as absorber layer into solution processed organic solar cells. By adding the processing additive 1,8-diiodooctane (DIO) to the host solvent 1,2dichlorobenzene (DCB), the solar cell fill factor increased to remarkable $70 \%$ and the power conversion efficiency approached 4.6\%. Low-energy scanning transmission electron microscopy (low-keV STEM) investigations indicated a finer bulk morphology of the active layer upon deposition from DCB:DIO. Further, the low-energy shoulder of the absorption spectrum was enhanced, indicating stronger polymer aggregation. According to external quantum efficiency measurements, the enhanced absorption also promoted better photon harvesting. Grazing incidence $\mathrm{X}$-ray diffraction experiments revealed face-on polymer aggregates being beneficial for the vertical hole transport.

\section{INTRODUCTION}

In recent years, the joint efforts of chemists, physicists, material scientists, and process engineers promoted a continuous improvement of organic solar cell power conversion efficiencies (PCE), today exceeding $10 \%$ in single junction devices. ${ }^{1}$ The PCE improvements partly resulted from device engineering, optical and electrical simulation, progress in analytical methods, and a detailed understanding of process-structure relationships and its impact on the active layer morphology. ${ }^{2-7}$ Advanced absorber materials exhibited internal quantum efficiencies close to one. ${ }^{8}$ Others enabled an enhanced spectral coverage of the solar spectrum. ${ }^{9,10}$ In particular, copolymers comprising acceptor and donor units offer manifold design possibilities. ${ }^{11}$ Among them, copolymers with a carbazole unit have been discussed intensively. ${ }^{12}$ One of the first polymers comprising a carbazole moiety was poly $\left[N-9^{\prime}\right.$-heptadecanyl-2,7-carbazole-alt5,5-(4',7'-di-2-thienyl-2', $1^{\prime}, 3^{\prime}$-benzothiadiazole)] (PCDTBT) that initially enabled $3.6 \%$ efficient, non-optimized solar cells. ${ }^{13}$ By changing the device architecture and the fabrication process, the PCE improved to $6.1 \%{ }^{8}$ which was further increased to $6.9 \%$ after discovering a thickness-dependent fill factor (FF) because of a laterally oriented morphology. ${ }^{14}$ By systematically incorporating a series of different acceptor building blocks into a 2,7-carbazole copolymer, Leclerc studied the effect of acceptor units on the lowest unoccupied molecular orbital (LUMO) energy levels of the copolymers and the effect of the monomer symmetry on its molecular order and crystallinity. ${ }^{15}$ The LUMO level is correlated to the strength of the electron-withdrawing acceptor monomer, while the highest occupied molecular orbital (HOMO) energy level is governed by the carbazole moiety. Within the study of Leclerc, the highest PCEs were achieved for PCDTBT with its symmetric acceptor monomers allowing for a higher degree of crystalline order. In a similar approach, a dialkoxy-substituted benzothiadiazole acceptor unit and a linear side group attached to the carbazole unit caused an all-planar copolymer that enabled solar cells with a PCE of 5.4\%. ${ }^{16}$ Accordingly, several modifications of carbazole polymers with a variety of quinoxaline acceptor monomers have been investigated with respect to their performance in organic photovoltaics (OPV). ${ }^{17-19}$ On the other hand, 2-alkyl-2H-benzotriazole acceptor units have enabled copolymers with high FFs and

Received: February 28, 2013

Revised: April 9, 2013 
Scheme 1. Synthesis of the Benzotriazole Monomer 5 and Polymer PCDTPBt<smiles>Fc1cc(-n2nc3c(Br)ccc(Br)c3n2)cc(F)c1F</smiles>

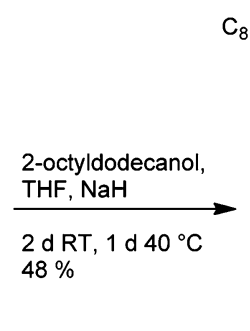

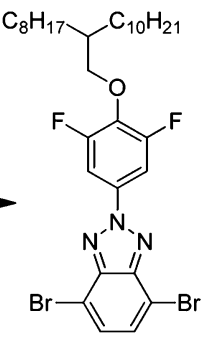

2

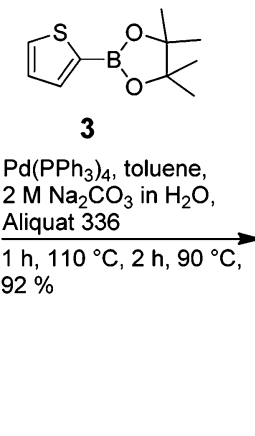

$2 \mathrm{M} \mathrm{Na}_{2} \mathrm{CO}_{3}$ in $\mathrm{H}_{2} \mathrm{O}$, Aliquat 336 $\mathrm{h}, 110^{\circ} \mathrm{C}, 2 \mathrm{~h}, 90^{\circ} \mathrm{C}$, $2 \%$

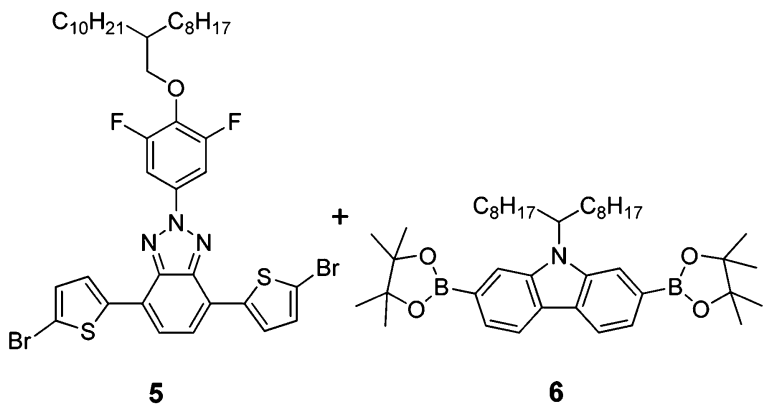

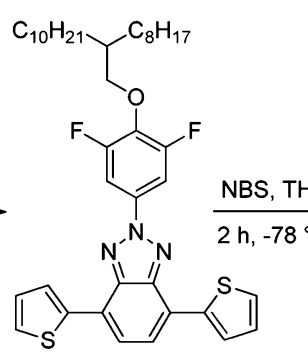

4

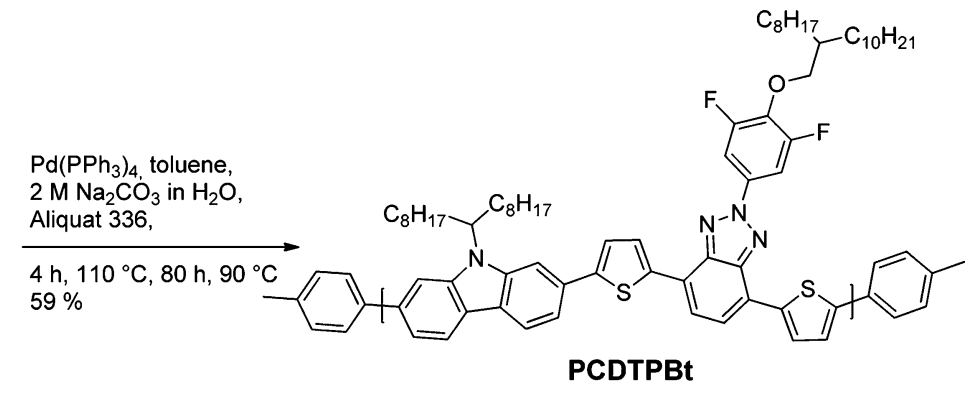

device PCEs. ${ }^{20-23}$ We recently investigated the impact of structural modifications of the 2-phenyl-2H-benzotriazole acceptor unit on the energy levels of thiophene oligomers ${ }^{24}$ and polymers. ${ }^{25,26}$

In this work we combine 2-phenyl-2H-benzotriazole units with an octyldodecyloxy substituent with the well-studied carbazole monomers and synthesize the light-absorbing polymer (poly[ $N-9^{\prime}$-heptadecanyl-2,7-carbazole-alt-5,5- $\left(4^{\prime}, 7^{\prime}\right.$ di-2-thienyl-2' -(3,5-difluoro-4-octyldodecyloxyphenyl)-2' $H$ benzotriazole)]), (Scheme 1), hereafter referred to as PCDTPBt. Then we built solar cells comprising blends from PCDTPBt and [6,6]-phenyl $\mathrm{C}_{71}$-butyric acid methyl ester $\left(\mathrm{PC}_{71} \mathrm{BM}\right)$ and studied the impact of the processing additive 1,8-diiodooctane (DIO) on the morphology of the bulk heterojunctions $(\mathrm{BHJ})$. DIO is well-known to impact the optoelectronic properties of the solar cells by utilizing the selective, differential solubility for one of the active layer components. ${ }^{27-30}$ Here, the addition of DIO led to a significant enhancement of the FF and short current density and consequently increased the PCE. The influence of DIO on the absorber morphology was analyzed by grazing incidence $\mathrm{X}$ ray diffraction (GIXD) and low-energy scanning transmission electron microscopy (low-keV STEM).

\section{EXPERIMENTAL SECTION}

Materials and Characterization. THF was dried over $\mathrm{Na}$ and benzophenone, distilled, and stored under argon if necessary. Reagents (reagent grade) were purchased from commercial sources and used without further purification. All air-sensitive reactions were carried out using standard Schlenk techniques under argon. Macherey-Nagel precoated TLC plates (Alugram SIL G/UV $\mathrm{UV}_{254}, 0.2 \mathrm{~mm}$ ) were used for thin-layer chromatography (TLC) analyses. Silica gel $60 \mathrm{M}$ (Macherey-Nagel, 0.04-0.063 mm, 230-400 mesh) was used as the stationary phase for column chromatography. ${ }^{1} \mathrm{H},{ }^{13} \mathrm{C}$, and ${ }^{19} \mathrm{~F}$ NMR spectra were recorded on Bruker DPX $300\left({ }^{1} \mathrm{H}, 300 \mathrm{MHz} ;{ }^{13} \mathrm{C}\right.$, $\left.75.5 \mathrm{MHz} ;{ }^{19} \mathrm{~F}, 282 \mathrm{MHz}\right)$, DPX $400\left({ }^{1} \mathrm{H}, 400 \mathrm{MHz} ;{ }^{13} \mathrm{C}, 101 \mathrm{MHz}\right)$, and DPX $500\left({ }^{1} \mathrm{H}, 500 \mathrm{MHz} ;{ }^{13} \mathrm{C}, 126 \mathrm{MHz} ;{ }^{19} \mathrm{~F}, 471 \mathrm{MHz}\right)$ spectrometers, and chemical shifts are reported as $\delta$ values (ppm) and referenced to residual ${ }^{1} \mathrm{H}$ or ${ }^{13} \mathrm{C}$ signals in deuterated solvents. ${ }^{31}$ HRMS data were recorded on a Bruker Daltonics Apex IV FT-ICR, and ESI HRMS data were recorded on a Bruker Daltronics ESI micrOTOF-Q instrument. UV/Vis absorption spectra were obtained from a PerkinElmer Lambda 18, and fluorescence spectra were received from a PerkinElmer LS $50 \mathrm{~B}$. Gel permeation chromatography (GPC) was performed in THF (HPLC grade, stabilized with $2.5 \mathrm{ppm} \mathrm{BHT)}$ at RT. GPC analyses were run on an Agilent Technologies system at a flow rate of $1 \mathrm{~mL} / \mathrm{min}$ using an IsoPump G1310 A, a diode array UV detector (G1315B), and PSS columns (Polymer Standards Service, Mainz, Germany; 10E2, 10E3, and 10E5 Å, $5 \mu, 8 \times 300 \mathrm{~mm}$ ). All molecular weights were determined versus PS calibration (PS standards from PSS, Mainz, Germany). Cyclic voltammetry was performed on PCDTPBt with a computer-controlled Model 602D electrochemical analyzer/workstation of $\mathrm{CH}$ Instruments with a glassy carbon disk $(\Phi=1 \mathrm{~mm})$ as working electrode on $0.2 \mathrm{mM}$ solutions of molecules in dried and oxygen-free dichloromethane with $0.1 \mathrm{M}$ tetrabutylammonium hexafluorophosphate (electrochemical grade, Fluka) as supporting electrolyte, a platinum wire counter electrode, and a $\mathrm{Ag} / \mathrm{AgI}$ reference electrode (silver wire immersed in a Pyrex tube containing $0.2 \mathrm{M} \mathrm{Bu}_{4} \mathrm{NPF}_{6}+0.02 \mathrm{M} \mathrm{Bu}_{4} \mathrm{NI}$ in $\mathrm{MeCN}$ ) which was separated from the main solution by a ceramic frit. Redox potentials were referenced against ferrocene/ferrocenium $\left(\mathrm{Fc} / \mathrm{Fc}^{+}\right)$. The corresponding highest occupied molecular orbital (HOMO) and lowest unoccupied molecular orbital (LUMO) were calculated using onset potentials of thin polymer films and using the absolute value of $-4.8 \mathrm{eV}$ to vacuum for the $\mathrm{Fc} / \mathrm{Fc}^{+}$redox potential. ${ }^{32}$ Differential scanning calorimetry (DSC) was performed on a Mettler Toledo DSC $823^{\mathrm{e}}$. Thermogravimmetric analysis (TGA) was carried out on a Mettler Toledo TGA/SDTA $851^{\mathrm{e}}$.

Synthesis. 4,7-Dibromo-2-(3,5-difluoro-4-(2-octyldodecyloxy)phenyl)-2H-benzotriazole (2). Under an argon atmosphere 2octyldodecanol ( $863 \mathrm{mg}, 0.228 \mathrm{mmol}$ ) was added (in one portion) to a stirring suspension of sodium hydride (60\% in paraffin, $173 \mathrm{mg}$, $7.29 \mathrm{mmol})$ in THF $(30 \mathrm{~mL})$. After stirring for $1 \mathrm{~h}$ at RT and heating to reflux for a few minutes 4,7-dibromo-2-(3,4,5-trifluorphenyl)- $2 \mathrm{H}$ benzotriazole $(1,70 \mathrm{mg}, 0.103 \mathrm{mmol})$ was added in one portion. The resulting mixture was stirred at RT for 2 days and at $40{ }^{\circ} \mathrm{C}$ for $24 \mathrm{~h}$. After cooling to RT and careful addition of water the product was 
extracted with cyclohexane $(3 \times 50 \mathrm{~mL})$, and the combined organic phases were washed with water $(2 \times)$ and with brine and then dried over $\mathrm{Na}_{2} \mathrm{SO}_{4}$. After the solvent was evaporated purification by column chromatography on silica gel using EtOAc/n-heptane (2/98) as eluent yielded the product as viscous colorless oil $(815 \mathrm{mg}, 48 \%) .{ }^{1} \mathrm{H}$ NMR $\left(400 \mathrm{MHz}, \mathrm{CDCl}_{3}\right): \delta \mathrm{ppm} 8.18-7.91(\mathrm{~m}, 2 \mathrm{H}), 7.48(\mathrm{~s}, 2 \mathrm{H}), 4.13(\mathrm{~d}$, $J=5.39 \mathrm{~Hz}, 2 \mathrm{H}), 1.84-1.71(\mathrm{~m}, 1 \mathrm{H}), 1.55-1.19(\mathrm{~m}, 32 \mathrm{H}), 0.90-0.87$ $(\mathrm{m}, 6 \mathrm{H}) \cdot{ }^{13} \mathrm{C}$ NMR $\left(101 \mathrm{MHz}, \mathrm{CDCl}_{3}\right): \delta \mathrm{ppm} 156.03$ (dd, $J=$ 249.75, $7.08 \mathrm{~Hz}), 144.67,137.83(\mathrm{t}, J=13.98 \mathrm{~Hz}), 133.74(\mathrm{t}, J=$ $12.07 \mathrm{~Hz}), 130.86,110.48,110.13,106.34-105.23(\mathrm{~m}), 77.93(\mathrm{t}, J=$ $2.88 \mathrm{~Hz}), 39.03,32.08,31.05,30.14,29.82,29.80,29.77,29.73,29.51$, 29.48, 26.91, 22.85, 14.27. ${ }^{19} \mathrm{~F}$ NMR $\left(282 \mathrm{MHz}, \mathrm{CDCl}_{3}\right): \delta \mathrm{ppm}$ $-125.47(\mathrm{~s}, 2 \mathrm{~F})$. ESI HRMS $m / z\left(\mathrm{M}^{+}\right)$calcd for $\mathrm{C}_{32} \mathrm{H}_{45} \mathrm{Br}_{2} \mathrm{~F}_{2} \mathrm{~N}_{3} \mathrm{ONa}$ ${ }^{+}:$706.1809; found 706.1790.

2-(3,5-Difluoro-4-(2-octyldodecyloxy)phenyl)-4,7-di(thiophen-2yl)-2H-benzotriazole (4). A solution of $2(583 \mathrm{mg}, 0.850 \mathrm{mmol})$ and the pinacol ester of 2-thienylboronic acid $3(563 \mathrm{mg}, 2.55 \mathrm{mmol})$ in a mixture of toluene $(50 \mathrm{~mL}) 2 \mathrm{M}$ aqueous $\mathrm{Na}_{2} \mathrm{CO}_{3}$ solution $(12 \mathrm{~mL})$ and Aliquat $336(20 \mathrm{mg})$ was purged with argon for about $1 \mathrm{~h}$. $\mathrm{Pd}\left(\mathrm{PPh}_{3}\right)_{4}(19.8 \mathrm{mg}, 17.1 \mu \mathrm{mol})$ was added in one portion, and the reaction mixture was stirred for $1 \mathrm{~h}$ at reflux temperature and $3 \mathrm{~h}$ at $90{ }^{\circ} \mathrm{C}$. The reaction mixture was allowed to cool to $\mathrm{RT}$ and diluted with $\mathrm{CH}_{2} \mathrm{Cl}_{2}$. After washing with water $(2 \times)$ and brine and drying over $\mathrm{Na}_{2} \mathrm{SO}_{4}$, the solvent was evaporated, and the bright yellow substance was purified by column chromatography on silica gel using $\mathrm{CH}_{2} \mathrm{Cl}_{2}$ / petrol ether $(1 / 9)$ as eluent. 4 was received as an amorphous yellow solid (542 mg, 92\%). ${ }^{1} \mathrm{H}$ NMR (500 MHz, $\left.\mathrm{CD}_{2} \mathrm{Cl}_{2}\right): \delta$ ppm 8.14 (dd, $J=3.66,1.14 \mathrm{~Hz}, 2 \mathrm{H}), 8.10-8.03(\mathrm{~m}, 2 \mathrm{H}), 7.65(\mathrm{~s}, 2 \mathrm{H}), 7.44(\mathrm{dd}$, $J=5.08,1.13 \mathrm{~Hz}, 2 \mathrm{H}), 7.22(\mathrm{dd}, J=5.08,3.66 \mathrm{~Hz}, 2 \mathrm{H}), 4.15(\mathrm{~d}, J=$ $5.50 \mathrm{~Hz}, 2 \mathrm{H}), 1.84-1.75(\mathrm{~m}, 1 \mathrm{H}), 1.59-1.47(\mathrm{~m}, 2 \mathrm{H}), 1.47-1.10(\mathrm{~m}$, $30 \mathrm{H}), 0.90-0.87(\mathrm{~m}, 6 \mathrm{H}) .{ }^{13} \mathrm{C}$ NMR $\left(126 \mathrm{MHz}, \mathrm{CD}_{2} \mathrm{Cl}_{2}\right): \delta \mathrm{ppm}$ $156.50(\mathrm{dd}, J=248.39 \mathrm{~Hz}), 142.90,139.32,137.43(\mathrm{t}, J=14.27 \mathrm{~Hz})$, $134.69(\mathrm{t}, J=12.22 \mathrm{~Hz}), 128.19,127.28,126.08,123.81,123.66$, $106.16-105.13(\mathrm{~m}), 78.33(\mathrm{t}, J=2.55 \mathrm{~Hz}), 53.93,53.72,53.50,53.28$, $53.07,38.95,32.00,30.94,30.08,29.75,29.73,29.70,29.67,29.44$, 29.42, 26.80, 22.78, 13.96. ${ }^{19} \mathrm{~F}$ NMR (282 $\left.\mathrm{MHz}, \mathrm{CDCl}_{3}\right): \delta \mathrm{ppm}$ $-125.91(\mathrm{~s}, 2 \mathrm{~F})$. MALDI HRMS $\mathrm{m} / z\left(\mathrm{M}^{+}\right)$calcd for $\mathrm{C}_{40} \mathrm{H}_{51} \mathrm{~F}_{2} \mathrm{~N}_{3} \mathrm{OS}_{2}^{+}$: 691.3436; found 691.3435.

4,7-Bis(5-bromothiophen-2-yl)-2-(3,5-difluoro-4-(2octyldodecyloxy)phenyl)-2H-benzotriazole (5). In a flame-dried flask, NBS (186 mg, $1.05 \mathrm{mmol}$ ) was added in one portion to a solution of 4 (349 $\mathrm{mg}, 0.504 \mathrm{mmol})$ in dry THF $(20 \mathrm{~mL})$ at $-78{ }^{\circ} \mathrm{C}$ under exclusion of light. After stirring for $2 \mathrm{~h}$ the mixture was allowed to warm to RT and stirred for additional $16 \mathrm{~h}$. The mixture was added to $\mathrm{MeOH}$, and the resulting solid was filtered, dried in vacuo, and then purified by column chromatography on silica gel using $\mathrm{CH}_{2} \mathrm{Cl}_{2} /$ cyclohexane $(3 / 97)$ as eluent to yield the product as viscous amorphous yellow solid (368 mg, 86\%). ${ }^{1} \mathrm{H}$ NMR (400 MHz, $\left.\mathrm{CD}_{2} \mathrm{Cl}_{2}\right): \delta$ ppm $7.92-7.73(\mathrm{~m}, 2 \mathrm{H}), 7.62(\mathrm{~d}, J=3.93 \mathrm{~Hz}, 2 \mathrm{H}), 7.26$ $(\mathrm{s}, 2 \mathrm{H}), 7.07(\mathrm{~d}, J=3.93 \mathrm{~Hz}, 2 \mathrm{H}), 4.14(\mathrm{~d}, J=5.38 \mathrm{~Hz}, 2 \mathrm{H})$, $1.85-1.76(\mathrm{~m}, 1 \mathrm{H}), 1.63-1.18(\mathrm{~m}, 32 \mathrm{H}), 0.91-0.87(\mathrm{~m}, 6 \mathrm{H}) .{ }^{13} \mathrm{C}$ NMR (101 MHz, $\left.\mathrm{CD}_{2} \mathrm{Cl}_{2}\right): \delta$ ppm $155.94(\mathrm{dd}, J=248.58 \mathrm{~Hz}), 142.01$, $140.57,137.10(\mathrm{t}, J=14.16 \mathrm{~Hz}), 133.74(\mathrm{t}, J=12.28 \mathrm{~Hz}), 130.97$, $127.01,122.85,122.59,113.56,105.68-104.10(\mathrm{~m}), 77.91(\mathrm{t}, J=$ $2.60 \mathrm{~Hz}) 39.01,32.03,30.98,30.12,29.79,29.76,29.72,29.47,29.46$, 26.86, 22.80, 13.99. ${ }^{19} \mathrm{~F} \mathrm{NMR}\left(286 \mathrm{MHz}, \mathrm{CD}_{2} \mathrm{Cl}_{2}\right): \delta \mathrm{ppm}-125.72(\mathrm{~s}$, 2F). MALDI HRMS $\mathrm{m} / z\left(\mathrm{M}^{+}\right)$calcd for $\mathrm{C}_{40} \mathrm{H}_{49} \mathrm{Br}_{2} \mathrm{~F}_{2} \mathrm{~N}_{3} \mathrm{OS}_{2}{ }^{+}$: 847.1646; found 847.1653.

PCDTPBt. A solution of $5(82.14 \mathrm{mg}, 0.0967 \mathrm{mmol})$ and 6 $(63.56 \mathrm{mg}, 0.0967 \mathrm{mmol})$ and few drops of Aliquat 336 in a mixture of toluene $(5 \mathrm{~mL})$ and $2 \mathrm{M} \mathrm{Na}_{2} \mathrm{CO}_{3}$ in water $(1.5 \mathrm{~mL})$ were purged with argon for about $1 \mathrm{~h}$. Then $\mathrm{Pd}\left(\mathrm{PPh}_{3}\right)_{4}(7 \mathrm{mg}, 6 \mu \mathrm{mol})$ was added in one portion. The reaction was stirred for $4 \mathrm{~h}$ at $110^{\circ} \mathrm{C}$ and $80 \mathrm{~h}$ at $90{ }^{\circ} \mathrm{C}$. Then the polymer was end-capped with $p$-tolylboronic acid $(15 \mathrm{mg}, 0.110 \mathrm{mmol})$ for $1 \mathrm{~h}$ at $130^{\circ} \mathrm{C}$ and $p$-bromotoluene $(0.05 \mathrm{~mL}$, $70 \mathrm{mg}, 0.409 \mathrm{mmol}$ ) for $2 \mathrm{~h}$ at $130{ }^{\circ} \mathrm{C}$. After cooling to RT, the aqueous phase was separated, and the polymer was precipitated by addition of the organic phase to $\mathrm{MeOH}$. After filtration through a Soxhlet thimble the polymer was extracted with $\mathrm{MeOH}$ for $5 \mathrm{~h}$, acetone, $n$-hexane, and $\mathrm{CHCl}_{3}$ until the extracts were colorless. Then the residues were dissolved with chlorobenzene $(\mathrm{CB})$ and concentrated in vacuo. The $\mathrm{CHCl}_{3}$ fraction was precipitated with $\mathrm{MeOH}$ and filtered through the same Soxhlet thimble again and extracted with $\mathrm{CH}_{2} \mathrm{Cl}_{2}$ until the extracts were colorless. The solid residue was then extracted with 1,2-dichlorobenzene (DCB, 120 mbar, $140{ }^{\circ} \mathrm{C}$ ), and the solvent was removed by vacuum distillation (Vigreux). After removal of the solvent, the $\mathrm{CB}$ and DCB fractions were combined, redissolved in hot DCB $(\sim 3 \mathrm{~mL})$, and precipitated with $\mathrm{MeOH}$. The precipitate was collected by filtration and dried in vacuo at $80{ }^{\circ} \mathrm{C}$ to yield a deep red solid $(62.6 \mathrm{mg}, 59 \%) .{ }^{1} \mathrm{H}$ NMR $\left(500 \mathrm{MHz}, 396 \mathrm{~K}, 1,2\right.$-dichlorobenzene- $\left.d_{4}\right): \delta \mathrm{ppm} 8.96-8.33(\mathrm{~m}$, $2 \mathrm{H}), 8.22(\mathrm{~d}, J=3.48 \mathrm{~Hz}, 2 \mathrm{H}), 8.15(\mathrm{~d}, J=8.54 \mathrm{~Hz}, 2 \mathrm{H}), 8.12(\mathrm{~d}, J=$ $8.06 \mathrm{~Hz}, 2 \mathrm{H}), 8.05(\mathrm{~s}, 2 \mathrm{H}), 7.71(\mathrm{~s}, 2 \mathrm{H}), 7.68(\mathrm{~d}, J=7.98 \mathrm{~Hz}, 2 \mathrm{H})$, $7.57(\mathrm{~d}, J=3.66 \mathrm{~Hz}, 2 \mathrm{H}), 4.87(\mathrm{br}, 1 \mathrm{H}), 4.41-4.11(\mathrm{~m}, 2 \mathrm{H}), 2.57(\mathrm{~m}$, $2 \mathrm{H}), 2.26-2.14(\mathrm{~m}, 2 \mathrm{H}), 1.96-1.86(\mathrm{~m}, 1 \mathrm{H}), 1.71-1.58(\mathrm{~m}, 2 \mathrm{H})$, $1.56-1.01(\mathrm{~m}, 54 \mathrm{H}), 0.94-0.84(\mathrm{~m}, 6 \mathrm{H}), 0.81-0.78(\mathrm{~m}, 6 \mathrm{H}) .{ }^{19} \mathrm{~F}$ NMR $\left(471 \mathrm{MHz}, 396 \mathrm{~K}, 1,2\right.$-dichlorobenzene- $\left.d_{4}\right): \delta \mathrm{ppm}-123.55(\mathrm{br}$, 2F). GPC (THF, polystyrene): $M_{\mathrm{n}}=136000 \mathrm{~g} / \mathrm{mol}$, PDI $=3.7$.

Solar Cells. Solar cells were fabricated according to an inverted glass/ITO/ZnO-PVP/PCDTPBt:PC $\mathrm{P}_{71} \mathrm{BM} / \mathrm{MoO}_{3} / \mathrm{Ag}$ solar cell architecture (inset Figure 2c). Structured, indium tin oxide-covered glass slides (ITO, thickness $t=150 \mathrm{~nm}$, sample size $16 \mathrm{~mm} \times 16 \mathrm{~mm}$, surface resistivity $\rho_{\mathrm{s}}=12 \Omega / \square$ ) were cleaned with acetone and isopropyl alcohol and then dried in a nitrogen stream in a class 1000 cleanroom. Sol-gel $\mathrm{ZnO}$ was prepared according to the process described by Subbiah et al. $^{33}$ Therefore, zinc acetate dihydrate $\left(\mathrm{Zn}\left(\mathrm{CH}_{3} \mathrm{COO}\right)_{2} \cdot 2 \mathrm{H}_{2} \mathrm{O}, 99.999 \%\right.$ trace metals basis, Sigma-Aldrich, $55 \mathrm{mg}$ ) and polyvinylpyrrolidone ( $\mathrm{PVP},\left(\mathrm{C}_{6} \mathrm{H}_{9} \mathrm{NO}\right)_{n}$, weight-average molecular weight $\left(M_{\mathrm{w}}\right) \sim 1300000$, Sigma-Aldrich, $15 \mathrm{mg}$ ) were dissolved in $5 \mathrm{~mL}$ of ethanol under stirring for $10 \mathrm{~min}$ at $70^{\circ} \mathrm{C}$. After adding $15 \mu \mathrm{L}$ of ethanolamine $\left(\mathrm{NH}_{2} \mathrm{CH}_{2} \mathrm{CH}_{2} \mathrm{OH}, \geq 99.0 \%\right.$, SigmaAldrich), the solution was stirred for further $2 \mathrm{~h}$. The sol-gel $\mathrm{ZnO}$ was spin-coated on top of the ITO glass substrate and annealed at $200{ }^{\circ} \mathrm{C}$ for $30 \mathrm{~min}$. Then the substrates were swayed in acetone, rinsed with water, and dried with nitrogen. The $\mathrm{ZnO}-\mathrm{PVP}$ nanocomposite thickness $t=25 \mathrm{~nm}$ was determined with a stylus profiler (DektakXT, Bruker AXS GmbH). PCDTPBt and $\mathrm{PC}_{71} \mathrm{BM}$ (Solenne, 99\%) were dissolved in 1,2-dichlorobenzene (DCB, anhydrous, 99\%, SigmaAldrich) at a polymer concentration of $7 \mathrm{mg} / \mathrm{mL}$. According to preliminary results (data not shown here) we focus our investigations on optimized polymer:fullerene blending ratios, i.e., a PCDTPBt:PC ${ }_{71} B M$ ratio of $1: 3$ when depositing from pure DCB and a ratio of 1:2 upon deposition from DCB comprising 3 vol \% DIO (DCB:DIO). These light absorbing layers were spin-coated $(60 \mu \mathrm{L}$ solution, $\left.80{ }^{\circ} \mathrm{C}\right)$ under a nitrogen atmosphere. $\mathrm{A} \mathrm{MoO}_{3}(7 \mathrm{~nm}) / \mathrm{Ag}$ $(80 \mathrm{~nm})$ electrode was vacuum deposited through a shadow mask in a Lesker Spectros system at $5 \times 10^{-7}$ mbar base pressure defining an active area of $10.5 \mathrm{~mm}^{2}$. A spectrally monitored Oriel $300 \mathrm{~W}$ solar simulator was used to simulate sunlight at 0.8 suns according to the spectral distribution of the ASTM-G173-03e1 standard for global solar irradiance. $^{34}$ The current density-voltage $(J-V)$ characteristics of the solar cells were recorded with a source measure unit (Keithley 238). After encapsulation of the solar cells, the external quantum efficiency (EQE) was measured under ambient conditions. The EQE setup comprises a $450 \mathrm{~W}$ xenon light source, an optical chopper $(47.7 \mathrm{~Hz})$, a $300 \mathrm{~mm}$ monochromator (LOT-Oriel), a custom-designed current amplifier (DLPCA-S Femto Messtechnik), and a digital lock-in amplifier (eLockin 203 Anfatec). A modified photoreceiver (OE200-S Femto Messtechnik) with a Si/InGaAs sandwich diode was used to monitor the stability of the monochromatic light beam. Initial calibration was carried out with a reference silicon diode (Thorlabs, NIST traceable calibration). The total absorption of the solar cells was determined in reflective mode on the same devices (Lambda 1050, PerkinElmer, equipped with a $150 \mathrm{~mm}$ integrating sphere).

$X$-ray Scattering. Thin films of neat PCDTPBt, PCDTPBt:PC ${ }_{71} B M$ (from DCB), and PCDTPBt:PC ${ }_{71} B M$ (from DCB:DIO) were spin-coated on Si substrates. Their microstructure was investigated by GIXD under a nitrogen atmosphere at the beamline P03 of PETRA III at DESY (Hamburg) with an X-ray 
a)

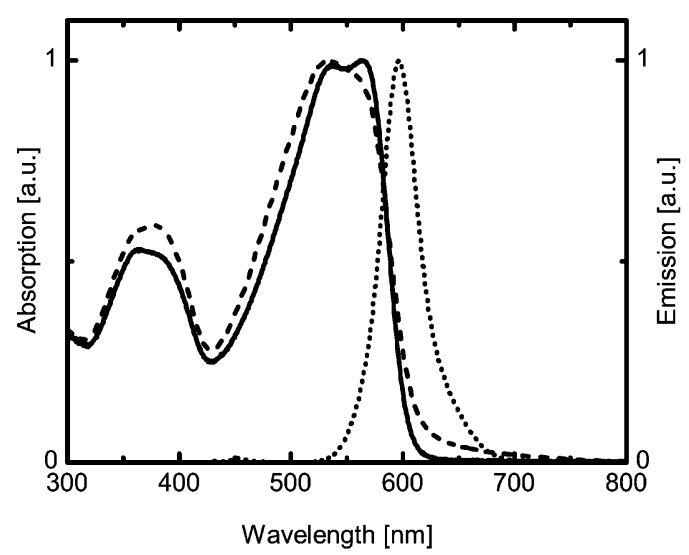

b)

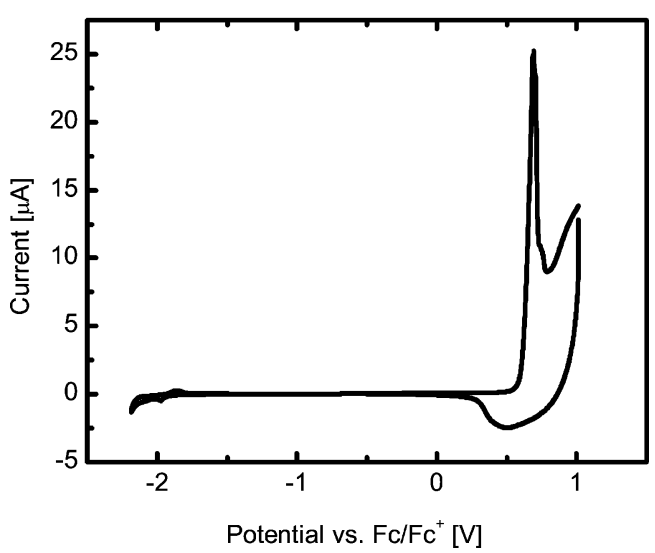

Figure 1. (a) UV/Vis absorption spectra of PCDTPBt in DCB solution (solid line) and thin film (cast from DCB, dashed line). Emission spectra in $\mathrm{DCB}$ (dotted line). (b) CV of thin film of PCDTPBt drop-cast from CB on a glassy carbon disk electrode in $\mathrm{MeCN}$ with $n$ - $\mathrm{Bu}_{4} \mathrm{NPF}_{6}$ as supporting electrolyte. The sweep rate is $0.05 \mathrm{~V} / \mathrm{s}$.

wavelength of $0.96 \AA$ and an incidence angle $\alpha_{\mathrm{i}}=0.21^{\circ}$ using a $300 \mathrm{k}$ PILATUS detector.

Electron Microscopy. The active layer was deposited atop a poly(3,4-ethylenedioxythiophene):polystyrenesulfonate (PEDOT:PSS, $45 \mathrm{~nm}$, Clevios P VP AI4083, Heraeus) sacrificial layer. By dropping some water on the surface, small pieces of the active layer floated off and were transferred onto a TEM grid. The bulk morphology properties of the active layers were studied with low-energy scanning transmission electron microscopy (low-keV STEM) at $15 \mathrm{keV}$. A standard scanning electron microscope (FEI Strata 400S) was used which is equipped with a 16-bit semiconductor STEM detector below the sample holder. ${ }^{35-37}$ Composition-sensitive imaging was performed by using the high-angle annular dark-field (HAADF) segment of the STEM detector. The surface topography of the samples was imaged by scanning electron microscopy (SEM) using secondary electrons which are collected with the "through lens" detector. The chemical composition was analyzed by energy-dispersive X-ray spectroscopy (EDXS) with a Bruker XFlash 5010 EDXS system. The surface topography of the ZnO-PVP nanocomposite was studied by secondary-electron SEM imaging with a Zeiss Supra 55VP.

\section{RESULTS AND DISCUSSION}

Synthesis of PCDTPBt. The synthesis of the bisbrominated benzotriazole monomer is shown in Scheme 1. 4,7-Dibromo-2(3,4,5-trifluorophenyl)-2H-benzotriazole $(1)^{24}$ was subjected to nucleophilic aromatic ipso substitution of a fluoride by treatment with sodium 2-octyldodecanolate. Even though there is always a certain amount of meta substituted byproduct, which is difficult to separate, $\mathbf{2}$ could be isolated in acceptable yields (48\%) after purification by column chromatography. Disubstitution has not been observed under these reaction conditions.

The bis-brominated benzotriazole 5 was prepared via Suzuki reaction of 3 with 2 and subsequent bromination with NBS. Purification by column chromatography was easy due to the solubilizing, long and branched 2-octyldodecyl chain. Notably, the respective Stille coupling reaction led to inferior yields and complex reaction mixtures.

The carbazole monomer 6 was prepared by methods known from the literature: The 2,7-dibromo-9H-carbazole was synthesized according to the method presented by Müllen, ${ }^{38}$ while the alkylation and the preparation of the bisboronic acid was conducted by the method of Leclerc. ${ }^{13}$ Suzuki polycondensation between 5 and $\mathbf{6}$ produced the copolymer poly $\left[N-9^{\prime}\right.$-heptadecanyl-2,7-carbazole-alt-5,5-(4',7'-di-2-thien-
yl-2'-(3,5-difluoro-4-octyldodecyloxyphenyl)-2'H-benzothiadiazole)] (PCDTPBt), which was end-capped with $p$-tolyl groups, precipitated from $\mathrm{MeOH}$, and subjected to Soxhlet extraction with various solvents. A restricted solubility prohibits higher yields since PCDTPBt could only partially be re-extracted from the Soxhlet thimble. The solid residue in the thimble was insoluble even in hot DCB.

The GPC analysis in THF (vs PS) suggests that the polymer has a rather high molecular weight $\left(M_{\mathrm{n}}=136 \mathrm{~kg} / \mathrm{mol}\right.$, $M_{\mathrm{w}}=503 \mathrm{~kg} / \mathrm{mol}$; Supporting Information Figure S1). However, these data have to be considered carefully since aggregation due to the restricted solubility in THF might result in larger measurement errors. RT solutions of PCDTPBt in $\mathrm{DCB}$ are highly viscous. According to the onset of weight loss in TGA, thermal decomposition starts at $400{ }^{\circ} \mathrm{C}$ (see Supporting Information Figure S2). DSC does not show any clear transitions, and no melting was observed when heating to $300{ }^{\circ} \mathrm{C}$ under an optical microscope.

The UV/Vis absorption spectra of the polymer are shown in Figure 1a. Generally, the absorption in thin films is slightly broader $\left(E_{\mathrm{g}}{ }^{\text {opt }}=2.02 \mathrm{eV}\right)$ than in solution, and the intensity ratios between the peak maxima vary to a certain extent. When compared to PCDTBT $\left(E_{\mathrm{g}}{ }^{\mathrm{opt}}=1.88 \mathrm{eV}\right)$ and the respective quinoxaline copolymer (PCDTQx; $\left.E_{\mathrm{g}}{ }^{\text {opt }}=2.02 \mathrm{eV}\right){ }^{15}$ the acceptor strength of the 2-phenyl-2H-benzotriazole unit comes closer to the quinoxaline than to the thiadiazole building block. PCDTPBt shows a sharp emission peak at $597 \mathrm{~nm}$ (full width at half-maximum $(\mathrm{fwhm})$ of $1150 \mathrm{~cm}^{-1}$ ); the Stokes shift of $980 \mathrm{~cm}^{-1}$ is rather low.

Cyclic voltammetry $(\mathrm{CV})$ in thin films on a glassy carbon disk electrode indicates that the polymers act as hole conductors. An intense reversible oxidation signal at $0.55 \mathrm{~V}$ and a weak irreversible reduction signal at $-1.86 \mathrm{~V}$ (Figure $1 \mathrm{~b}$ ) indicates a HOMO energy level at $-5.35 \mathrm{eV}$ and a LUMO energy level of $-2.94 \mathrm{eV}$ vs vacuum, respectively. The resulting $E_{\mathrm{g}}{ }^{\mathrm{CV}}$ of PCDTPBt therefore is $0.4 \mathrm{eV}$ larger than the optical band gap $E_{\mathrm{g}}{ }^{\text {opt }}$. We note that especially the n-doped state in $\mathrm{CV}$ can be very sensitive to trace oxygen and water or might react with the electrolyte or solvent. Here, we derive the LUMO energy level from $\mathrm{HOMO}+E_{\mathrm{g}}{ }^{\mathrm{opt}}=-3.34 \mathrm{eV}$ vs vacuum. The HOMO level of PCDTPBt is below the air oxidation threshold $E=-5.27 \mathrm{eV}$, which is necessary to achieve air stability. ${ }^{39}$ 
a)

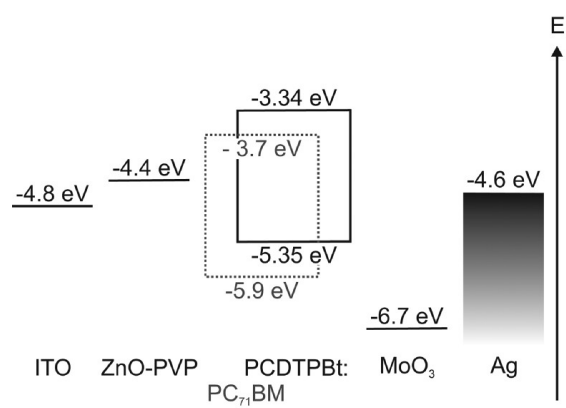

c)

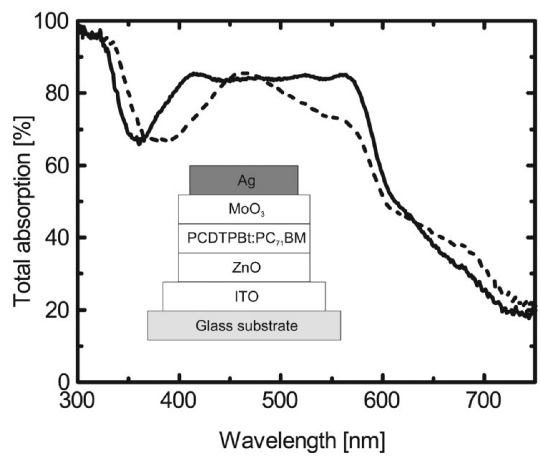

b)

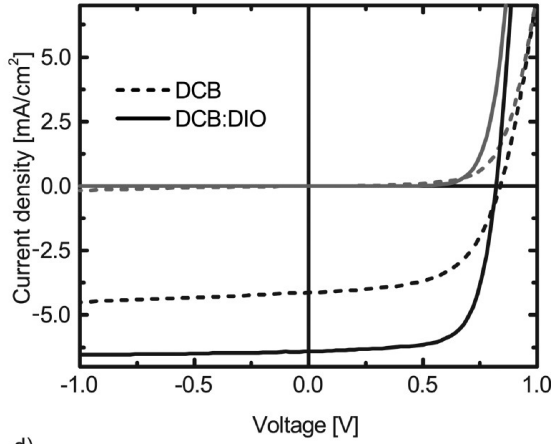

d)

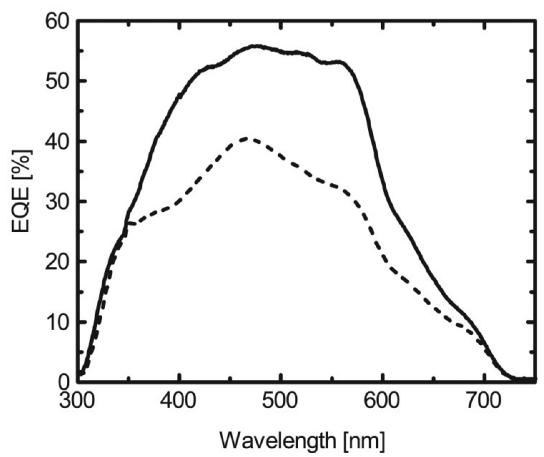

Figure 2. (a) Proposed energy level diagram of the PCDTPBt:PC ${ }_{71} \mathrm{BM}$ solar cells. (b) $J-V$ characteristics of photovoltaic devices fabricated from DCB (dashed line) or DCB:DIO (solid line) solution under illumination (black line) and in the dark (gray line). (c) Total absorption of the solar cells, measured in reflective mode using an integrating sphere. Inset: layer stack. (d) External quantum efficiency. All data measured on the same devices.

Solar Cells. Solar cells were built in an inverted device architecture. The device layer sequence is shown in Figure 2c, inset. The $\mathrm{ZnO}-\mathrm{PVP}$ nanocomposite bottom electrode was deposited from solution onto structured ITO glass substrates. To remove the PVP from the $\mathrm{ZnO}-\mathrm{PVP}$ surface, the samples were washed in acetone and rinsed with water. The change of the $\mathrm{ZnO}-\mathrm{PVP}$ film surface topography during the washing process is depicted in the SEM images in Figure S14a and Figure S14b: more and finer features become visible, indicating PVP removal from the surface of the $\mathrm{ZnO}-\mathrm{PVP}$ nanocomposite film. A similar change of the topography was observed by Small et al. for UV ozone-treated $\mathrm{ZnO}-\mathrm{PVP}$ films. ${ }^{40}$

Next, the PCDTPBt:PC ${ }_{71} B M$ layer was spin-cast atop the $\mathrm{ZnO}-\mathrm{PVP}$ nanocomposite film. With a LUMO level energy of about $-3.7 \mathrm{eV}, \mathrm{PC}_{71} \mathrm{BM}$ is an ideal acceptor for PCDTPBt. ${ }^{41,42}$ The polymer:fullerene LUMO level difference is close to the commonly assumed exciton binding energy of $0.3 \mathrm{eV}$ (Figure $2 a)$, ensuring proper exciton dissociation ${ }^{11,15,43}$ while at the same time leading to a remarkably high device voltage of $V_{\text {oc }}=840 \mathrm{mV}$.

Both $\mathrm{MoO}_{3}$ layer and $\mathrm{Ag}$ electrode were thermally evaporated as described in the Experimental Section. Since the n-doped $\mathrm{MoO}_{3}$ exhibits a high electron affinity of EA = $6.7 \mathrm{eV}$, it does not act as electron blocking layer. ${ }^{44}$ Instead, it is commonly assumed that band bending occurs at the interface leading to an interface dipole and consequently to an improved hole extraction. ${ }^{45}$

We compared active layers deposited from pure DCB with layers deposited from the solvent system DCB:DIO. The respective $J-V$ graphs are depicted in Figure $2 \mathrm{~b}$, and the obtained key performance data and layer thicknesses are summarized in Table 1. Adding DIO to the DCB solution increases the PCE by a factor of 1.8. The open-circuit voltage

Table 1. Photovoltaic Properties of Inverted PCDTPBt:PC ${ }_{71}$ BM Solar Cells Deposited from Pure DCB and from DCB:DIO

\begin{tabular}{lccccc}
\multicolumn{1}{c}{ solvent } & $\begin{array}{c}\text { active layer thickness } \\
{[\mathrm{nm}]}\end{array}$ & $\begin{array}{c}J_{\mathrm{sc}} \\
{\left[\mathrm{mA} / \mathrm{cm}^{2}\right]}\end{array}$ & $\begin{array}{c}V_{\mathrm{oc}} \\
{[\mathrm{mV}]}\end{array}$ & $\begin{array}{c}\mathrm{FF} \\
{[\%]}\end{array}$ & $\begin{array}{c}\text { PCE } \\
{[\%]}\end{array}$ \\
DCB & 68 & 4.1 & 840 & 58 & 2.5 \\
DCB:DIO & 75 & 6.4 & 820 & 70 & 4.6 \\
\hline
\end{tabular}

$V_{\text {oc }}$ decreases only marginally. However, the FF and the shortcurrent density $J_{s c}$ improve remarkably. The improvement of the FF to $70 \%$ can partly be attributed to a decrease of the series resistance $R_{\mathrm{s}}$ as derived from the slope of the solar cell current density under forward bias and under illumination, and by an increase of the parallel resistance $R_{\mathrm{p}}$, as derived from the slope in the third quadrant of the $J-V$ graph. Additionally, a high FF indicates a balanced electron and hole mobility. ${ }^{42-44}$

In order to investigate the origin of the photocurrent enhancement, we determined the total absorption (Figure 2c) and the EQE (Figure 2d) of devices after encapsulation. For devices with active layers that were fabricated from DCB:DIO solution, the total absorption exhibits a broadened absorption plateau between 414 and $563 \mathrm{~nm}$. We attribute the improved absorption at $560 \mathrm{~nm}$ to a stronger polymer aggregation. It is known that aggregation often causes a change of the absorption coefficient ${ }^{45-47}$ leading to shifted thin film interference patterns which might also explain the improved absorption in the $410 \mathrm{~nm}$ region. 
Similarly, three new features become visible in the EQE spectra (Figure 2d) of the DCB:DIO sample, i.e., at $432 \mathrm{~nm}$ $(\mathrm{EQE}=52.5 \%)$, at $526 \mathrm{~nm}(\mathrm{EQE}=54.5 \%)$, and at $557 \mathrm{~nm}$ $(\mathrm{EQE}=53.2 \%)$ with an overall maximum at $476 \mathrm{~nm}$ $(\mathrm{EQE}=55.9 \%)$. In addition, the quantum yield for films deposited from DCB:DIO is increased over the entire absorption spectrum.

We further investigated the impact of the processing additive DIO on the active layer nanomorphology by a GIXD analysis. Figure 3 depicts a series of GIXD measurement results that
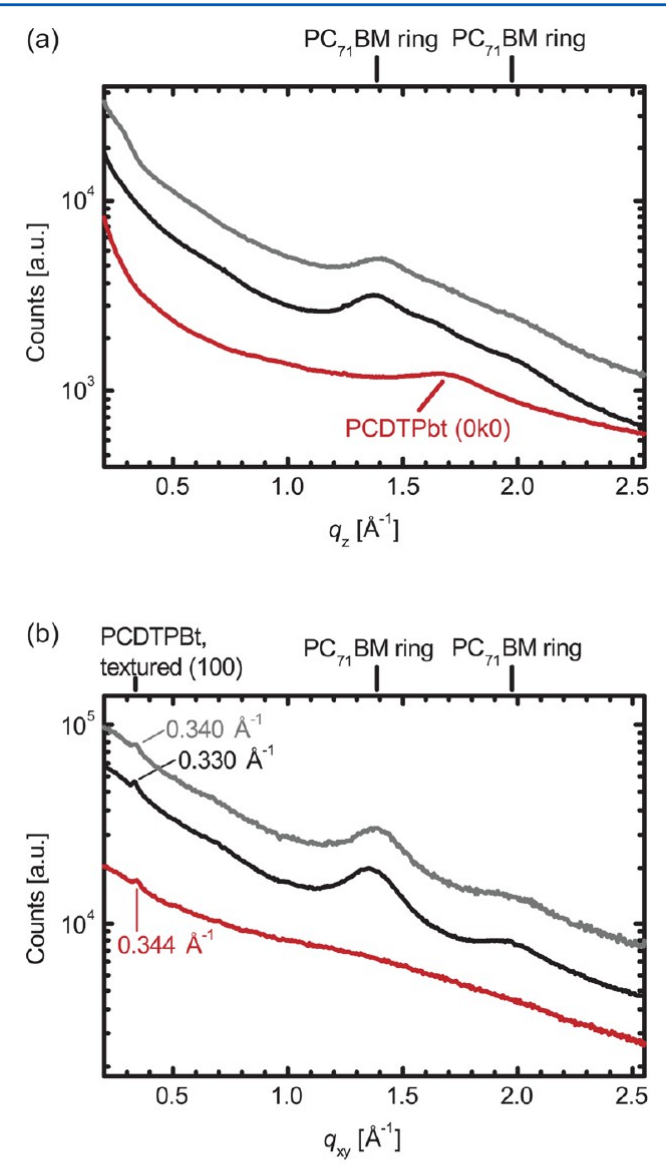

(c)

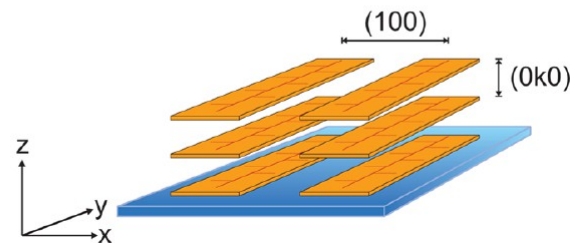

Figure 3. (a) Out-of-plane and (b) in-plane GIXD patterns of neat PCDTPBt (red line), PCDTPBt:PC ${ }_{71} \mathrm{BM}$ (black line), and PCDTPBt:PC ${ }_{71} \mathrm{BM}$ processed with DIO (gray line). (c) Face-on oriented PCDTPBt. The polymer backbone is oriented along $y, \pi-\pi$ stacking occurs in the out-of-plane direction, and the side groups are oriented in-plane (here along $x$ ).

allow for comparison of the molecular order of the neat polymer film and the PCDTPBt:PC ${ }_{71} \mathrm{BM}$ (DCB) blend with the PCDTPBt:PC ${ }_{71} \mathrm{BM}$ (DCB:DIO) blend. The GIXD data in Figure 3a shows a cut through the measured data in $q_{z}$ direction, which gives information about the molecular structure perpendicular to the sample surface, while Figure $3 \mathrm{~b}$ shows a cut in $q_{x y}$ direction yielding in-plane structural information. For the neat polymer, reflections in $q_{z}=1.7 \AA^{-1}$ and $q_{x y}=0.34 \AA^{-1}$ are found which correspond to lattice spacings of 3.7 and $18.5 \AA$, respectively. According to investigations of the structurally similar PCDTBT, we attribute these reflections to the $(0 k 0) \pi-\pi$-stacking and (100) interlayer stacking. ${ }^{15,52}$ Remarkably, both lattice spacings are smaller than those observed for PCDTBT, i.e., 4.6 and $21.4 \AA$, ${ }^{52}$ and other structural similar poly(2,7-carbazole) derivatives, i.e., 4.4-4.9 and 20.7-22.3 $\AA^{15}{ }^{15}$ indicating a dense and hence favorable packing of PCDTPBt. The $(0 k 0)$ reflection is only visible in the out-of-plane direction, while the (100) reflection appears only in the in-plane direction, indicating that the PCDTPBt crystallites' aromatic planes preferentially orient face-on on the substrate surface as shown in Figure 3c. We note that both reflections are broad and comparatively weak, indicating that crystalline domains are small and must coexist with significant amounts of amorphous PCDTPBt.

Both the blend from DCB and the blend from DCB:DIO exhibit the (0k0) and (100) reflections; i.e., the crystalline polymer domains are textured in a face-on configuration in both samples. Films deposited from DCB:DIO again exhibit a reflection at $q_{x y}=0.34 \AA^{-1}$ corresponding to a lattice spacing of $\sim 18.5 \AA$, but for the blend deposited from pure DCB a slight shift of the (100) reflection by $-0.01 \AA^{-1}$ to $q_{x y}=0.33 \AA^{-1}$ is observed, indicating that the stacking distance is slightly increased to $\sim 19 \AA$. .

Besides the polymer features, a powder ring occurs at $q_{x y}=$ $q_{z}=1.37 \AA^{-1}$ in the blend (DCB), which corresponds to $\mathrm{PC}_{71} \mathrm{BM}$ domains with random orientation. ${ }^{53}$ The average fwhm of $\Delta q=0.22 \AA^{-1}$ can be used to estimate a lower bound of the crystalline $\mathrm{PC}_{71} \mathrm{BM}$ domain size $L_{\min }=25 \AA$ using the Scherrer equation $L=0.9 \times 2 \pi / \Delta q$. Importantly, since various lattice constants contribute to the fwhm in paracrystals, this value must be considered as a lower estimate. In the film that was deposited from DCB:DIO, the $\mathrm{PC}_{71} \mathrm{BM}$ powder ring is observed at $q_{z}=q_{x y}=1.40 \AA^{-1}$, indicating slightly denser packing. The fwhm is unchanged compared to the DCB case. A weaker powder ring at $q_{z} \approx q_{x y} \approx 1.97 \AA^{-1}$ is also visible, again shifting to larger $q$ in the sample from DCB:DIO solution so that we tentatively assign this ring to $\mathrm{PC}_{71} \mathrm{BM}$, too.

Though there is a strong amorphous background, we assume that the observed face-on orientation and the subsequent vertical $\pi-\pi$-stacking improve hole transport to the electrode and charge extraction. ${ }^{51,55}$ Further, in the DIO:DCB case the lattice spacing of the polymer is slightly reduced.

Nevertheless, the crystallinity of both blends has turned out low. While GIXD is sensitive to crystalline features, we probed the active layer with low-keV HAADF STEM (Figure 4a, DCB; Figure 4b, DCB:DIO), providing sensitive material contrast. $^{35-37}$ The surface topography of the same sample regions was studied by SEM (Figure 4c,d). The low-keV HAADF STEM images, Figure $4 \mathrm{a}$ (DCB) and Figure 4b (DCB:DIO), show a finer network of brighter and darker regions appearing upon addition of DIO. Images with higher and lower magnification can be found in Figure S15.

SEM images of the same sample regions (Figure 4c,d) reveal a topography change for films deposited from DCB:DIO solution. Features that appear dark in the low-keV HAADF STEM images also appear dark in the SEM images. We attribute this to polymer-rich domains in the bulk which form depressions from the surface.

This interpretation is further supported by an EDXS analysis which allows for distinction between the dominant molecular 

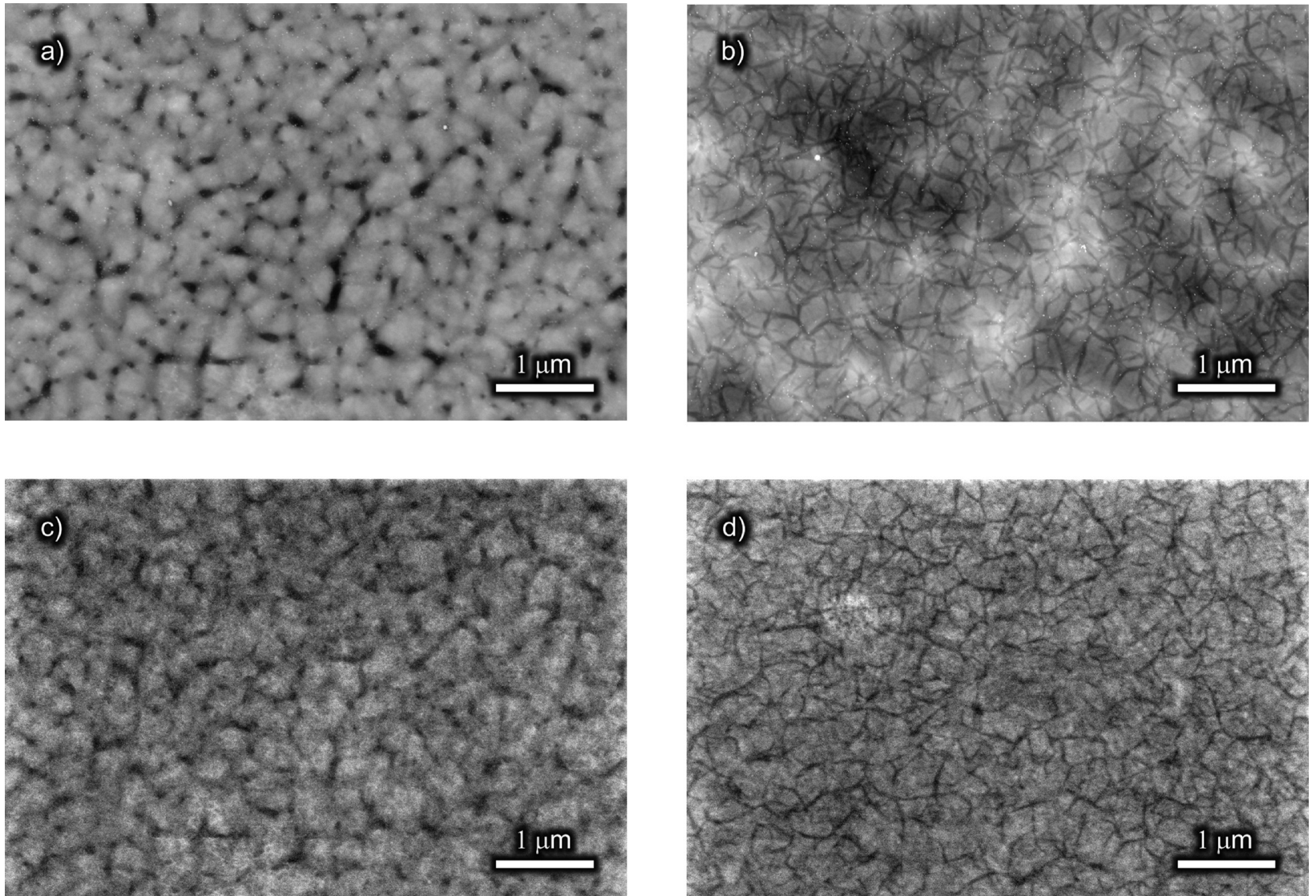

Figure 4. Low-keV HAADF STEM images of PCDTPBt:PC ${ }_{71} B M$ layers recorded at $15 \mathrm{keV}$ with the active layer deposited from (a) DCB and (b) DCB:DIO. EDXS was used to identify the darker phases as PCDTPBt-rich structures. (c, d) SEM surface topography images of the same sample regions depicted in $(a)$ and $(b)$.

contributions by probing the sulfur content in the different phases of the BHJ with high spatial resolution. The corresponding spectroscopic data sets are shown in Figure S16. In essence, the darker regions correspond to the $\mathrm{PCDTPBt}$-rich and the brighter regions to the $\mathrm{PC}_{71} \mathrm{BM}$-rich phases.

In summary, the solvent mixture DCB:DIO improves the morphology of the PCDTPBt:PC $\mathrm{P}_{71} \mathrm{BM}$ active layer in various ways. On the one hand, its admixture leads to a denser stacking of the polymers causing an increase of the low-energy absorption shoulder and, on the other hand, to a simultaneous reduction of the $\mathrm{BHJ}$ domains' size. In combination with the short $\pi$-stacking distance, enabling a strong intermolecular coupling, and the beneficial face-on configuration of PCDTPBt the PCE almost doubles compared to deposition from pure DCB.

\section{CONCLUSION}

We synthesized the conjugated polymer PCDTPBt combining a 2-phenyl-2H-benzotriazole acceptor unit with an octyldodecyloxy substituent and the well-established 2,7-functionalized carbazole donor unit. The polymer structure was probed with GIXD. PCDTPBt exhibits face-on oriented aggregates embedded in an amorphous PCDTPBt matrix. Notably, the polymer is more densely stacked than other carbazole-based polymers such as PCDTBT. When blending PCDTPBt with $\mathrm{PC}_{71} \mathrm{BM}$ in solar cells, the preferred face-on configuration of the neat polymer was preserved. Upon addition of the process additive DIO the solar cell PCE approached $4.6 \%$ and the FF reached remarkable $70 \%$. To understand the DIO influence, we probed the active layer morphology with low-keV HAADF STEM. The average domain size in the $\mathrm{BHJ}$ is reduced when deposited from DCB:DIO instead of pure DCB solution. At the same time, the low-energy shoulder in the absorption and EQE spectra becomes stronger, indicating enhanced polymer aggregation which is confirmed by complementary GIXD results.

\section{ASSOCIATED CONTENT}

\section{S Supporting Information}

MWD, TGA of the polymer, and NMR spectra of all new compounds; low-keV HAADF STEM images at different magnifications and EDX analysis. This material is available free of charge via the Internet at http://pubs.acs.org.

\section{AUTHOR INFORMATION}

\section{Corresponding Author}

*E-mail: alexander.colsmann@kit.edu (A.C.); hoeger@unibonn.de (S.H.).

\section{Notes}

The authors declare no competing financial interest.

\section{ACKNOWLEDGMENTS}

The authors acknowledge funding by the Deutsche Forschungsgemeinschaft (DFG) and the State of Baden-Württemberg through the DFG Center for Functional Nanostructures $(\mathrm{CFN})$ and the DFG-priority program 1355 "Elementary 
processes of organic photovoltaics". M.F.G.K. is further supported by the Karlsruhe School of Optics and Photonics (KSOP). The authors thank Jegadesan Subbiah (University of Melbourne) for suggesting the $\mathrm{ZnO}-\mathrm{PVP}$ nanocomposite and fruitful discussions and Stephan V. Roth for help with experiments at DESY. Manuel Reinhard (KIT, Germany) contributed with the SEM images of the $\mathrm{ZnO}-\mathrm{PVP}$ films.

\section{REFERENCES}

(1) Green, M. A.; Emery, K.; Hishikawa, Y.; Warta, W.; Dunlop, E. D. Prog. Photovoltaics Res. Appl. 2013, 21, 1-11.

(2) Liu, F.; Gu, Y.; Jung, J. W.; Jo, W. H.; Russell, T. P. J. Polym. Sci., Part B: Polym. Phys. 2012, 50, 1018-1044.

(3) Nagarjuna, G.; Venkataraman, D. J. Polym. Sci., Part B: Polym. Phys. 2012, 50, 1045-1056.

(4) Barnes, M. D.; Baghar, M. J. Polym. Sci., Part B: Polym. Phys. 2012, 50, 1121-1129.

(5) Sanyal, M.; Schmidt-Hansberg, B.; Klein, M. F. G.; Munuera, C.; Vorobiev, A.; Colsmann, A.; Scharfer, P.; Lemmer, U.; Schabel, W.; Dosch, H.; Barrena, E. Macromolecules 2011, 44, 3795-3800.

(6) Sanyal, M.; Schmidt-Hansberg, B.; Klein, M. F. G.; Colsmann, A.; Munuera, C.; Vorobiev, A.; Lemmer, U.; Schabel, W.; Dosch, H.; Barrena, E. Adv. Energy Mater. 2011, 1, 363-367.

(7) Schmidt-Hansberg, B.; Sanyal, M.; Klein, M. F. G.; Pfaff, M.; Schnabel, N.; Jaiser, S.; Vorobiev, A.; Müller, E.; Colsmann, A.; Scharfer, P.; Gerthsen, D.; Lemmer, U.; Barrena, E.; Schabel, W. ACS Nano 2011, 5, 8579-8590.

(8) Park, S. H.; Roy, A.; Beaupré, S.; Cho, S.; Coates, N.; Moon, J. S.; Moses, D.; Leclerc, M.; Lee, K.; Heeger, A. J. Nat. Photonics 2009, 3, 297-302.

(9) Li, Y.; Zou, Y. Adv. Mater. 2008, 20, 2952-2958.

(10) Li, Y. Acc. Chem. Res. 2012, 45, 723-733.

(11) Cheng, Y.-J.; Yang, S.-H.; Hsu, C.-S. Chem. Rev. 2009, 109, 5868-5923.

(12) Pisula, W.; Mishra, A. K.; Li, J.; Baumgarten, M.; Müllen, K. In Organic Photovoltaics; Brabec, C., Dyakonov, V., Scherf, U., Eds.; Wiley-VCH: Weinheim, 2009; Chapter 3, pp 93-128.

(13) Blouin, N.; Michaud, A.; Leclerc, M. Adv. Mater. 2007, 19, 2295-2300.

(14) Moon, J. S.; Jo, J.; Heeger, A. J. Adv. Energy Mater. 2012, 2, 304-308.

(15) Blouin, N.; Michaud, A.; Gendron, D.; Wakim, S.; Blair, E.; Neagu-Plesu, R.; Belletête, M.; Durocher, G.; Tao, Y.; Leclerc, M. J. Am. Chem. Soc. 2008, 130, 732-742.

(16) Qin, R.; Li, W.; Li, C.; Du, C.; Veit, C.; Schleiermacher, H.-F.; Andersson, M.; Bo, Z.; Liu, Z.; Inganäs, O.; Wuerfel, U.; Zhang, F. J. Am. Chem. Soc. 2009, 131, 14612-14613.

(17) Zhang, J.; Cai, W.; Huang, F.; Wang, E.; Zhong, C.; Liu, S.; Wang, M.; Duan, C.; Yang, T.; Cao, Y. Macromolecules 2011, 44, 894901.

(18) Lee, S. K.; Lee, W.-H.; Cho, J. M.; Park, S. J.; Park, J.-U.; Shin, W. S.; Lee, J.-C.; Kang, I.-N.; Moon, S.-J. Macromolecules 2011, 44, 5994-6001.

(19) Wang, E.; Hou, L.; Wang, Z.; Ma, Z.; Hellström, S.; Zhuang, W.; Zhang, F.; Inganäs, O.; Andersson, M. R. Macromolecules 2011, 44, 2067-2073.

(20) Min, J.; Zhang, Z.-G.; Zhang, S.; Zhang, M.; Zhang, J.; Li, Y. Macromolecules 2011, 44, 7632-7638.

(21) Price, S. C.; Stuart, A. C.; Yang, L.; Zhou, H.; You, W. J. Am. Chem. Soc. 2011, 133, 4625-4631.

(22) Min, J.; Zhang, Z.-G.; Zhang, S.; Li, Y. Chem. Mater. 2012, 24, $3247-3254$.

(23) Min, J.; Zhang, Z.-G.; Zhang, M.; Li, Y. Polym. Chem. 2013, 4, 1467-1473.

(24) Pasker, F. M.; Le Blanc, S. M.; Schnakenburg, G.; Höger, S. Org. Lett. 2011, 13, 2338-2341.
(25) Pasker, F. M.; Klein, M. F. G.; Sanyal, M.; Barrena, E.; Lemmer, U.; Colsmann, A.; Höger, S. J. Polym. Sci., Part A: Polym. Chem. 2011, 49, 5001-5011.

(26) Wettach, H.; Pasker, F.; Höger, S. Macromolecules 2008, 41, 9513-9515.

(27) Peet, J.; Kim, J. Y.; Coates, N. E.; Ma, W. L.; Moses, D.; Heeger, A. J.; Bazan, G. C. Nat. Mater. 2007, 6, 497-500.

(28) Lee, J. K.; Ma, W. L.; Brabec, C. J.; Yuen, J.; Moon, J. S.; Kim, J. Y.; Lee, K.; Bazan, G. C.; Heeger, A. J. J. Am. Chem. Soc. 2008, 130, 3619-3623.

(29) Lou, S. J.; Szarko, J. M.; Xu, T.; Yu, L.; Marks, T. J.; Chen, L. X. J. Am. Chem. Soc. 2011, 133, 20661-20663.

(30) Collins, B. A.; Li, Z.; Tumbleston, J. R.; Gann, E.; McNeill, C. R.; Ade, H. Adv. Energy Mater. 2013, 3, 65-74.

(31) Gottlieb, H. E.; Kotlyar, V.; Nudelman, A. J. Org. Chem. 1997, 62, 7512-7515.

(32) Pommerehne, J.; Vestweber, H.; Guss, W.; Mahrt, R. F.; Bässler, H.; Porsch, M.; Daub, J. Adv. Mater. 1995, 7, 551-554.

(33) Subbiah, J.; Amb, C. M.; Reynolds, J. R.; So, F. Sol. Energy Mater. Sol. Cells 2012, 97, 97-101.

(34) American Society of Testing \& Materials (ASTM). In Annual Book of ASTM Standards; ASTM International: West Conshohocken, PA, 2006; Vol. 14.04, Chapter 03e1: Standard Tables for Reference Solar Spectral Irradiances: Direct Normal and Hemispherical on $37^{\circ}$ Tilted Surface; DOI 10.1520/G0173-03E01.

(35) Pfaff, M.; Müller, E.; Klein, M. F. G.; Colsmann, A.; Lemmer, U.; Krzyzanek, V.; Reichelt, R.; Gerthsen, D. J. Microsc. 2011, 243, 3139.

(36) Klein, M. F. G.; Pfaff, M.; Müller, E.; Czolk, J.; Reinhard, M.; Valouch, S.; Lemmer, U.; Colsmann, A.; Gerthsen, D. J. Polym. Sci., Part B: Polym. Phys. 2012, 50, 198-206.

(37) Pfaff, M.; Klein, M. F. G.; Müller, E.; Müller, P.; Colsmann, A.; Lemmer, U.; Gerthsen, D. Microsc. Microanal. 2012, 18, 1380-1388.

(38) Dierschke, F.; Grimsdale, A. C.; Müllen, K. Synthesis 2003, 16, 2470-2472.

(39) de Leeuw, D.; Simenon, M.; Brown, A.; Einerhand, R. Synth. Met. 1997, 87, 53-59.

(40) Small, C. E.; Chen, S.; Subbiah, J.; Amb, C. M.; Tsang, S.-W.; Lai, T.-H.; Reynolds, J. R.; So, F. Nat. Photonics 2011, 6, 115-120.

(41) Liu, C.; Xiao, S.; Shu, X.; Li, Y.; Xu, L.; Liu, T.; Yu, Y.; Zhang, L.; Liu, H.; Li, Y. ACS Appl. Mater. Interfaces 2012, 4, 1065-1071.

(42) Ratcliff, E. L.; Meyer, J.; Steirer, K. X.; Armstrong, N. R.; Olson, D.; Kahn, A. Org. Electron. 2012, 13, 744-749.

(43) Koster, L. J. A.; Mihailetchi, V. D.; Blom, P. W. M. Appl. Phys. Lett. 2006, 88, 093511.

(44) Kroger, M.; Hamwi, S.; Meyer, J.; Riedl, T.; Kowalsky, W.; Kahn, A. Appl. Phys. Lett. 2009, 95, 123301.

(45) Subbiah, J.; Amb, C. M.; Irfan, I.; Gao, Y.; Reynolds, J. R.; So, F. ACS Appl. Mater. Interfaces 2012, 4, 866-870.

(46) Koster, L. J. A.; Mihailetchi, V. D.; Blom, P. W. M. Appl. Phys. Lett. 2006, 88, 052104.

(47) Mihailetchi, V.; Xie, H.; de Boer, B.; Koster, L.; Blom, P. Adv. Funct. Mater. 2006, 16, 699-708.

(48) Klein, M. F. G.; Pasker, F.; Wettach, H.; Gadaczek, I.; Bredow, T.; Zilkens, P.; Vöhringer, P.; Lemmer, U.; Höger, S.; Colsmann, A. J. Phys. Chem. C 2012, 116, 16358-16364.

(49) Clark, J.; Silva, C.; Friend, R. H.; Spano, F. C. Phys. Rev. Lett. 2007, 98, 206406.

(50) Clark, J.; Chang, J.-F.; Spano, F. C.; Friend, R. H.; Silva, C. Appl. Phys. Lett. 2009, 94, 163306.

(51) Agostinelli, T.; Lilliu, S.; Labram, J. G.; Campoy-Quiles, M.; Hampton, M.; Pires, E.; Rawle, J.; Bikondoa, O.; Bradley, D. D. C.; Anthopoulos, T. D.; Nelson, J.; Macdonald, J. E. Adv. Funct. Mater. 2011, 21, 1701-1708.

(52) Staniec, P. A.; Parnell, A. J.; Dunbar, A. D. F.; Yi, H.; Pearson, A. J.; Wang, T.; Hopkinson, P. E.; Kinane, C.; Dalgliesh, R. M.; Donald, A. M.; Ryan, A. J.; Iraqi, A.; Jones, R. A. L.; Lidzey, D. G. Adv. Energy Mater. 2011, 1, 499-504. 
(53) Agostinelli, T.; Ferenczi, T. A. M.; Pires, E.; Foster, S.; Maurano, A.; Müller, C.; Ballantyne, A.; Hampton, M.; Lilliu, S.; Campoy-Quiles, M.; Azimi, H.; Morana, M.; Bradley, D. D. C.; Durrant, J.; Macdonald, J. E.; Stingelin, N.; Nelson, J. J. Polym. Sci., Part B: Polym. Phys. 2011, 49, 717-724.

(54) Salleo, A.; Kline, R. J.; DeLongchamp, D. M.; Chabinyc, M. L. Adv. Mater. 2010, 22, 3812-3838.

(55) Schmidt-Hansberg, B.; Klein, M. F. G.; Sanyal, M.; Buss, F.; de Medeiros, G. Q. G.; Munuera, C.; Vorobiev, A.; Colsmann, A.; Scharfer, P.; Lemmer, U.; Barrena, E.; Schabel, W. Macromolecules 2012, 45, 7948-7955. 